University of Tulsa College of Law

TU Law Digital Commons

Articles, Chapters in Books and Other Contributions to Scholarly Works

2007

\title{
Copyrights and "Design-Around" Scholarship
}

Robert Spoo

Follow this and additional works at: http://digitalcommons.law.utulsa.edu/fac_pub

Part of the Law Commons

\section{Recommended Citation}

44 James Joyce Q. 563-85 (2007).

This Article is brought to you for free and open access by TU Law Digital Commons. It has been accepted for inclusion in Articles, Chapters in Books and Other Contributions to Scholarly Works by an authorized administrator of TU Law Digital Commons. For more information, please contact daniel-bell@utulsa.edu. 


\title{
Copyrights and "Design-Around" Scholarship
}

\author{
Robert Spoo
}

ULYSSES: THE NEW READER'S EDITION, edited by Danis Rose. Mousehole, Cornwall: Houyhnhnm Press Ltd., 2004. Ixxxiv +769 pp. $€ 30.00$.

THE SCANDAL OF "ULYSSES": THE LIFE AND AFTERLIFE OF A TWENTIETH CENTURY MASTERPIECE, by Bruce Arnold. Dublin: Liffey Press, 2004. 346 pp. $€ 19.95$.

JOYCE STUDIES ANNUAL 2003, edited by Thomas F. Staley. Austin: University of Texas Press, 2003. 184 pp. $\$ 32.00$ (individuals); $\$ 48.00$ (institutions); back issues $\$ 11.00$.

\begin{abstract}
patent is a formidable thing. In the United States, it affords Atwenty years of nearly ironclad protection to an inventor who can prove, after considerable expenditure of time and money, that some new process for manufacturing widgets is a novel and nonobvious addition to what legal practitioners call the "prior art"-all those processes for manufacturing widgets that others have thought up in the past. Once the federal government has conferred a patent upon an inventor, competitors must have a care. A successful invention inspires imitation, but if the imitation is too close, its author may get slapped with a lawsuit. In the high-dollar world of patents, losing an infringement suit can mean facing damages of millions or even billions of dollars. ${ }^{1}$

So imitators have to be as ingenious as the inventors they seek to imitate. Patent law encourages such ingenuity by permitting a clever competitor to "design around" a patent in such a way as to create a product that is the functional equivalent of the protected idea but narrowly avoids entering the forbidden zone of infringement. Economic policy also favors design-arounds. While non-infringing copycat products may threaten patentees' revenues, they also make the marketplace more competitive and drive down the price of products-consequences that are widely considered to be socially desirable. ${ }^{2}$ It takes skill and legal acumen to come up with a successful design-around. Many have devoted their careers to brainstorming these legitimate knockoffs.
\end{abstract}

The humanities are perhaps the last place we would expect to 
encounter this art of the barely legal approximation, but the past few years have witnessed the growing phenomenon of design-around scholarship. As copyrights grow longer and their owners become more chary of permissions, as publishers retreat from the exercise of fair use and take refuge in parsimonious word counts and rigid permissions policies, copyrights are coming to resemble closely guarded patents. ${ }^{3}$ This is a perverse development, and one that courts have historically frowned upon. In one well-known case, a copyright owner who had authored a set of simple rules for running a sweepstakes contest tried to prevent another promoter from using the same basic rules in its own contest materials. A panel of federal judges rejected this attempt to turn a copyright claim into a de facto patent: "We cannot recognize copyright as a game of chess in which the public can be checkmated."

\section{The Heirloom Fallacy: Grandmother's Necklace and Grandfather's Letter}

Traditionally, courts and legislatures have resisted what might be called the patentization of copyrights. Copyrights are porous rights. While they confer a monopoly on creative expression, the doctrine of fair use and the idea/expression dichotomy-to name two venerable limitations on copyright control-permit unauthorized use of portions of that expression. As the great Judge Learned Hand wrote of Abie's Irish Rose, Anne Nichols's 1920s stage comedy about IrishJewish intermarriage: "her copyright did not cover everything that might be drawn from her play; its content went to some extent into the public domain. ${ }^{5}$ Courts have long recognized the leaky nature of copyrights, but the judiciary is only one aspect of the chess game that keeps copyright law true to itself. Authors, editors, and, equally importantly in the present context, publishers must exercise the fairuse privilege or watch it atrophy. More than a few publishers, intimidated by the clamor of copyright owners, have lost their nerve.

Caught between assertive copyright holders and risk-averse publishers, many academic authors have experienced total market failure-a breakdown of bargaining with the copyright owner, coupled with a denial of fair use by the publisher. ${ }^{6}$ The breakdown is total because when denial of permission to quote (market failure) is combined with refusal to exercise fair use (closure of market alternatives), checkmate has occurred in copyright's chess game. If modernism is aptly defined as "that which is still propertized," it is also the case that in the hands of remote and unsympathetic owners, this property increasingly lacks one of property's traditional characteristics: social utility. Intellectual property that cannot be used is a deadweight loss to society. ${ }^{8}$ It is like grandmother's necklace, which is taken from its 
drawer once a year for a memorial caress. But an author's text is different from the one-of-a-kind necklace that is sentimentally hoarded. A text is an intangible public good that can be reproduced and disseminated at relatively little cost, for the social weal, without depletion of its source. ${ }^{9}$

Let's take a hypothetical case prompted by my simile of the necklace. James Joyce's grandson, Stephen James Joyce, or his wife, is believed to own the necklace with the inscribed ivory tablet which Joyce gave to Nora Barnacle in $1909 .{ }^{10}$ The necklace is a private, tangible chattel of a sort that would normally have a sentimental value far exceeding its market value. (Of course, this particular heirloom probably has an enhanced market value as well, because of the fame of its original purchaser.) Now consider another piece of property that is privately owned: the copyright in the letter, dated 3 September 1909, in which Joyce elaborately described for Nora the necklace (or "necklet," as he called it), its inscription, and the sadness and loneliness that lay behind his purchase of the gift (LettersII 245-46). The original document is held in the special collections of Cornell University and was first published in 1966. Stephen Joyce's public statements lead me to believe that, if asked, he might say that these two pieces of property-the necklace and the copyright-are fundamentally the same as far as ownership rights are concerned, the more so because they both involve "private" family matters. ${ }^{11}$ And Mr. Joyce might consider himself justified in refusing absolutely, on the one hand, to sell the necklace to a French banker and, on the other, to give an Australian Ph.D. candidate permission to reproduce the text of the letter in her dissertation. ${ }^{12}$

In treating both kinds of property as essentially private and priceless, an owner would be engendering what I have described as market failure; but only in the case of the refused permission would the market failure have significant public consequences. Let's call these common attitudes toward intellectual property the Heirloom Fallacy and the Pricelessness Problem. Both attitudes are rooted in the popular assumption that copyrights are the same as traditional kinds of property. As Lawrence Lessig has explained:

[O]rdinary people think about "property" differently [from intellectualproperty lawyers]. . . "Property," ordinary people think, is "absolute and mine forever." If you say to ordinary people, "What do you think of the idea of fair use of your property, or only having your property for limited times?" they are likely to think, "Well, that's weird. You don't have a fair use right to my car, nor are you able to say after a limited time the state can come in and take away my house."13

With the Heirloom Fallacy, a public good like an epistolary text 
is treated by the copyright holder as a wholly private, intimate possession, even though the original document may reside in a public archive or its contents may have been published. ${ }^{14}$ The Pricelessness Problem arises when this intangible property becomes emotionally charged with a pathos of uniqueness that removes it from the socializing forces of the marketplace, both of ideas and economics. These two overlapping views of "mine and thine"-the Heirloom Fallacy and the Pricelessness Problem-can combine to shut down the social utility of copyrighted works.

When copyrights are used as a tool for suppressing information, at least three parties are affected: "(1) the person who seeks or threatens to make the contested use ..., (2) the copyright owner who wants to keep the material from being copied . . . , and (3) the person or persons who would want to see the material (the potential recipients)."15 As a result of this "suppression triangle," as Wendy J. Gordon calls it ("Commodification" 175), the interests of the absent party-the public-are sacrificed. Here, Adam Smith's notion of the "invisible hand," that economic force which theoretically pilots private interest and social need into alignment, is inadequate to the task. ${ }^{16}$ The breakdown of bargaining might give some private, nonmonetary satisfaction to the copyright holder, but it results in a deadweight loss to society-the suppression both of the words contained in the document and of the scholarly analysis that would have framed and transformed those words for the enlightenment of readers. It is precisely this intellectually transformative act which is the essence of responsible, evidence-based scholarship in the humanities.

Unlike grandmother's necklace, grandfather's letter (and, even more clearly, his novel) is a public good, a piece of property that can inform, educate, and perhaps move countless readers. ${ }^{17}$ But because legislators have seen fit to extend copyright terms and thus to hand control of these public goods over to remote heirs and transferees-who, in some cases, are unaware of or indifferent to the social and cultural consequences of their attitudes-the distinction between grandmother's necklace and grandfather's letter is blurred in the minds of copyright owners and the public alike. And when a descendant, armed with lawyers, access to the popular press, and the prestige of genetic fortuity, makes it known that quotation from "private" family documents is strongly disfavored-even though the documents are already published or are held in collections open to the public-reliance on the fair-use privilege is likely to become a casualty. We have entered the Era of Forbidden Quotation.

Scholars and critics have increasingly resorted to strategies for sidestepping this problem. By trimming quotations to the bone or forgoing them altogether, by deleting all unpublished material or paraphrasing it nearly out of existence, by using public-domain edi- 
tions in place of better, copyrighted ones, academic authors are practicing the art of designing around copyrights. By "designing around copyrights" I do not mean the traditional scholarly exercise of honest fair-use quotation or informative paraphrase, but rather the skittish use of these time-honored tools, as if they did not lawfully exist or were no longer safe to employ as fully as in the past. Design-around scholarship often amounts to a kind of perverse self-denial-perverse because not warranted by the porous nature of copyrights.

We have seen this phenomenon take root in Joyce studies. A striking example, bordering on the bizarre, is found in J. C. C. Mays's bibliographic study, Fredson Bowers and the Irish Wolfhound, in which Mays had intended to reproduce Joyce's hand-drawn diagram of biological and evolutionary themes underlying "Oxen of the Sun."18 Permission to reproduce was denied, and in place of Joyce's drawing, Mays substituted the following black-bordered notice:

The copyright-holder has refused permission to reproduce the chosen illustration and the reader must therefore consult either the original in London or a facsimile-transcription. . . Meanwhile, visualize a sheet of paper containing nine enlarging ovals rising from the same basepoint, drawn to represent the stages of foetal growth. Minutely-written gynaecological details are inserted at the apex of eight of the nine ovals. Surrounding the design, crowding in from each corner of the page, are words and phrases chosen to illustrate successive phases in the evolution of English prose. (71)

This unreasonable facsimile shows how much is lost by the substitution of even a detailed "paraphrase" of Joyce's diagram. Copyright law's idea/expression dichotomy is little consolation for the reader deprived of Joyce's indispensable visual commentary on one of the most challenging episodes of Ulysses.

But scholarly design-arounds have not been confined to local troubleshooting. After the Joyce Estate repeatedly expressed opposition to Carol Loeb Shloss's biography of Lucia Joyce, she and her publisher removed numerous pages of quotations from letters and documents that would have fortified her challenging interpretation of the relationship between Lucia and her father. ${ }^{19}$ In another case, a textual scholar, believing that a request for permission to quote would be fruitless, developed a code by which the contents of newly discovered Ulysses manuscripts may be discussed without a single verbatim quotation from those materials. ${ }^{20}$ Another scholar, noted for his close textual study of the genetic development of Ulysses, has written several articles containing general descriptions and inventories of the recent manuscript discoveries but has scrupulously avoided offering extracts. ${ }^{21}$ The institutions that have paid millions of Euros or dollars for Joyce manuscripts have in a sense been cheated: in the 
age of digital reproduction and cyberspace, to own physical texts that cannot be displayed or copied is, paradoxically, to possess something unreal. The aura of the archives is diminished to the extent that their contents lack a reproductive dimension. ${ }^{22}$

The present review essay focuses on three symptoms of this era of increasingly patent-like copyrights and design-around scholarship: Danis Rose's New Reader's Edition of Ulysses, a text which is as overtly shaped by copyright law as by scholarly erudition; John Kidd's unachieved "Dublin Edition" of Ulysses which, according to Bruce Arnold's revised Scandal of "Ulysses," failed to see publication in part because it fell afoul of copyright restrictions; and the final Texas installment of Joyce Studies Annual, in which its editor, Thomas F. Staley, tells us that he elected to terminate the series when his original goal of publishing archive-based scholarship had come to seem impossible in light of the Joyce Estate's virtual ban on the quotation of unpublished Joyce materials.

\section{The New Lawyer's Edition of Ulysses}

In the United Kingdom and certain other European Union countries, lifetime-published editions of Ulysses entered the public domain when protection expired at the end of 1991, fifty years after Joyce's death. Shortly thereafter, the EU issued a directive that required EU countries to enact legislation extending copyright terms retroactively to seventy years post mortem auctoris. This meant that works which had been enjoying public-domain status, like Ulysses, were abruptly pulled back into copyright. The revived EU copyright in Ulysses will last, unless extended again, until the end of 2011-nearly a century of legal protection, all told. We are just beginning to see the distorting effects that such extravagantly long monopolies are having on culture. ${ }^{23}$ Danis Rose's revised edition of Ulysses-his "Reader's Edition"-is one example.

In 1997, Rose's original Reader's Edition was published simultaneously by Macmillan in the United Kingdom and the Lilliput Press in the Republic of Ireland. Even before the edition reached bookstores, the Joyce Estate initiated legal proceedings, ${ }^{24}$ alleging that Rose's unauthorized project infringed copyright and constituted the tort of "passing off": (a legal theory typically reserved for disputes between marketers of physical products). After years of sporadic litigation, Mr. Justice Lloyd of the English High Court, Chancery Division, ruled that Rose's Edition both did and did not violate the Joyce Estate's copyright. (The passing-off claim he rejected out of hand.) To the extent that Rose had made use of Ulysses manuscript materials which had been published after Joyce's death, the Reader's Edition was an infringing work, he held. But insofar as Rose drew upon versions of 
Ulysses published during Joyce's lifetime-and this constituted the majority of editorial borrowings-Rose was entitled to the benefits of a "compulsory license" which prevented the Estate from objecting to use of such lifetime editions and merely required Rose and his publisher to pay reasonable remuneration to the Estate. ${ }^{25}$

This compulsory license was one of the measures adopted in the United Kingdom to soften the impact of the revival of lapsed copyrights under the EU directive. Essentially, the compulsory license permits anyone to make use of a revived-copyright work like Ulysses without seeking authorization from the copyright owner. All that is required is that the user give the owner reasonable advance notice of the intended use and eventually pay a reasonable fee or royalty. If the parties cannot agree on a fee or royalty, the amount of compensation will be determined by Britain's Copyright Tribunal. The point of this exception is that, while the copyright owner is entitled to reasonable remuneration for use of the revived-copyright work, he or she has no power to refuse permission. Thus, the basic unfairness of revived copyrights is mitigated in the United Kingdom-though not necessarily in other countries of the EU, such as the Republic of Ireland, which did not adopt a comparable compulsory-license exception.

The United Kingdom's enlightened compulsory license takes the weapon of censorship out of the hands of copyright owners and substitutes a limited bargaining power. It also eliminates the specter of total market failure, at least with respect to revived-copyright works, and guarantees that the Pricelessness Problem and other property attitudes will not deprive the public of useful reprints, adaptations, and analyses of these works. The compulsory license underscores the difference between the necklace and the novel; only for the latter has a government interceded to protect the reliance interests of the public. As with an easement permitting non-owners a limited right of entry upon private land, or the state's exercise of eminent domain for some socially beneficial purpose, a compulsory license allows the public to gain access to its own culture. ${ }^{26}$

Rose's New Reader's Edition is a creature of the U. K. compulsory license. The section of Rose's introduction entitled "The Trials of the Reader's Edition" contains an illuminating discussion of the copyright litigation that the Joyce Estate launched against the first Reader's Edition, and of Justice Lloyd's ruling that the edition infringed copyright only with respect to readings that Rose had drawn from Joyce's unpublished or posthumously published manuscripts (xlii-lv). But it is Justice Lloyd's conclusion that Rose's use of the revived-copyright 1922 Ulysses - which constituted the bulk of the Reader's Edition-was shielded by the U. K. compulsory license that gave Rose the idea for the New Reader's Edition, which he dedicates to "Mr Justice Lloyd, whose Judgment defined the limits and inspired 
its rationale" $(\mathrm{lv})$.

Obedient to the law, which Rose calls "Lloyd's law" (with only partial accuracy, since the compulsory license was created by a government minister exercising legislative powers, not by a court), the New Reader's Edition scrupulously omits all manuscript readings that had condemned the Reader's Edition to legal sanction, and replaces what Rose calls his "isotext" (the assembled and unemended manuscript text that formed the basis of the first Reader's Edition) with "a new complex consisting of the 1922 first edition and the 1918 Little Review publication" (lxviii-lxix). Rose then emended this "new complex" according to the following rationale: "(1) with substantives, follow the 1922 edition/Little Review complex; and, (2) with accidentals, follow sound practice" (lxix). This way, Rose's base text and emendations were drawn entirely from lifetime-published materials that are covered by the United Kingdom compulsory license-except for certain emendations based on what Rose calls "sound practice." These latter corrections, quips Rose, "may on occasion reproduce a reading in the manuscript, but purely coincidentally" (lxix). After all he has been through, he is entitled to this bibliographic Irish bull.

Having prepared his New Reader's Edition, Rose published it, not in Ireland where a comparable compulsory-license exception has not been adopted, but in Cornwall under the laughing imprint "Houyhnhnm." The New Reader's Edition is a legal triumph in the sense that it points the way for others to make use of the U. K. compulsory license. At the same time, by internalizing copyright strictures as a salient feature of its editorial rationale, the Edition is necessarily shaped and to some degree distorted by legal limitations. For although Rose assures us that "nothing of any great significance to Ulysses has ... been lost" (lxix), he also admits that some desirable emendations could not be introduced "without breaching Lloyd's law" (lxxi).

We thus have an edition of Ulysses overtly shaped, in part, by the external compulsions of the law, and not solely by the scholarly decisions of the editor - a profoundly social, or sociolegal, text. ${ }^{27}$ The New Reader's Edition is the copyright antithesis of Hans Walter Gabler's edition of Ulysses. For while Gabler's inclusion of manuscript material was freely permitted and, according to some accounts, even encouraged by the copyright holder, ${ }^{28}$ the New Reader's Edition is the result of the scrupulous omission of manuscript readings-an edition by subtraction. As Seamus Deane points out in his foreword to the Edition, this is "a text that has incorporated into itself the practices of censorship that, in its initial form, it did so much to weaken" (vi). While it is important not to overlook the legal silver lining of the New Reader's Edition-its resourceful use of the U. K. compulsory license-it is undeniable that the volume is something more, and less, 
than the product of traditional editing: it is a symptom of the Era of Forbidden Quotation.

\section{The Scandal of the Norton Edition of Ulysses}

John Kidd's W. W. Norton Edition of Ulysses is another edition by subtraction, but in Kidd's case the end result was zero: the much-touted volume never appeared. No clear, candid explanation was ever given. Both Norton and Kidd occasionally alluded to copyright difficulties with the Joyce Estate (as discussed below), but the nature of those difficulties remained cloaked in mystery, and by the mid-1990s Kidd had so damaged his credibility that his explanations could not be relied on anyway. Yet at some point he had evidently concluded, as I did, ${ }^{29}$ that the 1922 Paris first edition of Ulysses-the edition he had chosen as his base text-is in the public domain in the United States. Norton may have shared or been persuaded of that belief, at least until intimidation or some other obstacle supervened. We may never know for sure.

Arnold's revised Scandal of "Ulysses": The Life and Afterlife of a Twentieth-Century Masterpiece sheds some light on the scandal of the much-promised Norton edition of Ulysses. Both Kidd and Norton laid the blame for the book's nonappearance on "copyright problems." ${ }^{30}$ Norton's president remarked in 2002 that because of "extensions to the copyright in the early 1990s, . . Kidd's edition can't be published for two decades." ${ }^{31}$ More recently, it was reported by D. T. Max that Stephen Joyce had declared himself "implacably opposed" to the Kidd edition (35). I do not know how accurate this is. Arnold notes only that Norton chose "to take the prudent course and seek copyright arrangements" and that Mary Cunnane of Norton referred to "our negotiations with the Estate" (297-98).

I suspect that if the immediate cause of the delay was copyright, the ultimate cause was Kidd's failure to finish the edition. Had he wrapped it up before the EU revival of copyrights in 1995, there might have been no obstacles in the United Kingdom, Ireland, and other parts of Europe. Arnold notes that Kidd "had given a warranty in his contract [with Norton] that the book was out of copyright," but he does not say whether this referred to the United States or the European Union (298). At any rate, by 1997, Arnold comments, Kidd's unforthcoming edition was apparently given up for dead by Norton and Lilliput (298). Arnold tells this story of false hopes and unkept promises in considerable detail, concluding that if "Kidd had moved more swiftly, and if Norton had been more determined over copyright, his edition of Ulysses might well have appeared" (298). Does this mean that Norton would have bargained more doggedly with the

Estate had Kidd tendered a finished text? Or was Norton just using 
copyright to cover its blunder in getting involved with this project in the first place?

Arnold's treatment of the Kidd phenomenon here is more cleareyed than in his first edition of The Scandal of "Ulysses," published in 1991. As a journalist, Arnold has always been in a position to recognize that Kidd, despite his talent and learning, was largely a creation of the media that promoted him as the boy who would make academia's flesh creep. But it is only in the new Scandal that Arnold records his skepticism of Kidd's claims and methods, along with a less dismissive attitude toward Gabler's achievement. Arnold now acknowledges Kidd's "ugly" self-aggrandizement and his failure "to deliver on promises" (225); he concedes that Kidd "never presented a balanced view of the differences between major errors and minor ones [in the Gabler edition of Ulysses]. And this was both tactically and strategically intended" (230). Of Kidd's 1988 attack on Gabler in the New York Review of Books-which Arnold described in the first Scandal as "alert[ing] real people to an academic travesty" 32 - he now concludes that Kidd's "choice of the [Harry] Thrift example [of textual error] was a tactic of picking the damning example to which was then added a host of lesser errors": "This created the false impression that they are all that bad. The Thrift mistake is indefensible on Gabler's part, but apart from the Culler/Buller mistake and the Conolly Norman one, all of Kidd's other examples of Gabler's errors can be justified. Kidd's article is rhetorically clever but perhaps intellectually disingenuous" (228). ${ }^{33}$ This is a stunning concession by an author who chose the word "scandal" with which to arraign Gabler's project. Indeed, Arnold's attempt to have it both ways in this revised volume - to insert newfound doubts about Kidd while retaining verbatim much of the anti-Gabler rhetoric of the first edition-results in an odd, double-voiced incoherence. It is strange, too, that it took Arnold more than a decade to notice Kidd's mean-spirited hyperbole; the evidence was all there in 1991 when Arnold published the first Scandal. Yet his new candor is marred by traces of the old Kiddolatry, unchanged from the 1991 text. Kidd is still "Parsifal-like" as he "emerges from the forest to redeem a damaged situation," someone who presents arguments "with admirable simplicity and clarity for so complicated a subject" (198). Charles Rossman is still "the new knight who had brought such sustenance to John Kidd's lonely assault" (249). In the years following the release of the first Scandal, Arnold had more than enough time to fall out of love with such ridiculous phrasemaking; certainly by 2004, this type of rhetorical glamour should have seemed mismatched to the reality of Kidd's "lonely assault."

But what was that reality exactly? We know that Kidd had immense erudition and drive; he had selective charm and scary aggressiveness. 
He could be ruthlessly captious and ingeniously plausible. He possessed an ability to communicate cagily simplified truths in a way that attracted journalists and devastated opponents-opponents who usually became verbose in their scramble to reach the high ground and deliver comprehensive rebuttals that left the media yawning. Kidd was a master of the heaped detail and a miser of the teacher's first duty: to show the true basis for disagreement. It was within his power to explain that the mass of minor textual delinquencies with which he charged Gabler was really a function of Gabler's having adopted a very different editorial approach from the one favored by Kidd. The only truly effective and honest way Kidd could have made that point was by publishing his own edition. Sadly, he was beset by physical illnesses that made his task difficult. It is also possible that the more he neared completion of his work, the more his edition came to resemble Gabler's. Did it seem that the Oedipal knife was turning back on him? Would the path that had begun in numerological sympathy with Gabler and then veered into acrimony lead back, by divergent theories, to intellectual agreement in the end? I once saw a copy of the introduction Kidd had drafted for his idling edition. Numerology took up a large part of the discussion, along with a screed on historical records as a basis for editorial choice. It would have been a controversial volume.

Arnold is a learned and witty journalist who nurses a mistrust of established academia. It is probably that quality that caused him to be smitten with Kidd in the first place. It also makes him sympathetic to Stephen James Joyce's bitter attacks on Joyce scholarship. "Stephen Joyce," declares Arnold, "has more than justice on his side in what he says and feels [about 'modern scholarship' on Joyce], as well as in what he does. One of the attitudes he adopts is a determined sense of, and desire for, family privacy". (317-18). I take this stuff to be mostly rhetoric. What "justice" does the Joyce Estate have "on [its] side" to support the claim that James Joyce, a famous person dead for more than sixty-five years now, is entitled to "privacy" as defined by his grandson? The law does not recognize such an expansive notion of privacy. As to the "more than justice" that Arnold ascribes to the Estate's position, what does that mean? Superior morality? Hereditary entitlement? Arnold goes on:

Not only is Stephen [Joyce] protective of his grandfather; he is also concerned with intrusions into the private lives of his grandmother, his father and mother, and his mother's earlier family, and Lucia, his aunt. It is a legitimate position to adopt, and if the protection of it requires a stern attitude towards copyright, the only effective control over information he can employ, then so be it. (318) 
"So be it," indeed-because little more than raw fiat supports the position that copyrights may properly be used to a gain "effective control over information" (318). Arnold's acceptance of the Joyce Estate's privacy argument is unfortunate, because that argument is so misconceived. Why? First, it is fundamentally incoherent. Nearly all of the documents that the Estate has declared off-limits to publishing scholars-letters by James Joyce and Joyce family members, essays and memoirs by Lucia Joyce and Helen Kastor Fleischman Joyce-are either already published or held in archives and collections that are generally open to the public. So these documents are not "private" in the sense that they are physically or legally inaccessible. We can learn any of their secrets; we just cannot quote our findings in articles and books or on the Internet. We can kiss but not tell. And how is our silence enforced? Through the climate of fear that many copyright holders have cultivated over the past two decades-decades during which it has been brought home to us, as never before, how "propertized" modernism really is.

The second reason why the Estate's privacy argument fails is related to the first. Suppose an unpublished letter by James Joyce to Harriet Shaw Weaver, held in a university archive, contained the following (wholly invented) remark: "Every day that passes makes me more certain that my daughter is the captive of a medical establishment that cannot follow or sympathize with the frolics and detours of the creative imagination. Sometimes I think they would break my spirit, too, if they could. And once my book is published, perhaps I will be declared fair game for these devourers of the spirit." Suppose further that a graduate student read this letter and wrote the following in her dissertation: "Joyce confided to Harriet Shaw Weaver his growing conviction that Lucia's doctors were unable to appreciate her creative spirit and its rebelliousness. He recognized in their obtuseness a culture that feared and hated true imagination, and he worried, in Blakean terms, that such 'devourers of the spirit' would condemn his Work in Progress." Has the student done anything that copyright law could punish? No-not in the United States anyway. Most of the discussion is lawful paraphrase of Joyce's words, permitted by copyright law's idea/expression dichotomy. And the quotation of a four-word phrase framed by transformative scholarly commentary is a core fair use, which under U.S. law extends to unpublished as well as published works. ${ }^{34}$ If the phrase "devourers of the spirit" is, in fact, Blake's and not Joyce's, then no copyright issues exist at all.

If copyright law permits our hypothetical scholar to write such a passage in her dissertation - a passage describing, through paraphrase and selective quotation, Joyce's deepest fears for his daughter and his own vulnerability as a creative personality - then what, legally and practically, has copyright to do with enforcing privacy? 
Not much. The porosity of copyrights permits our scholar to spill the beans; it is only Joyce's precise wording in its totality that copyright may control. And this is because copyrights are there to protect economic interests, not privacy interests. The "protection of privacy is not a function of the copyright law," as one U. S. court succinctly observed. ${ }^{35}$ And when copyrights are used as scarecrows ${ }^{36}$ to obtain "effective control over information," as Arnold puts it (318), we are witnessing something that is increasingly being recognized by lawyers and judges as "copyright misuse" - an attempt to extend copyright protection beyond its appropriate sphere. ${ }^{37}$ Copyright misuse was one of the issues posed by Shloss in her lawsuits against Stephen James Joyce and the Estate of James Joyce. ${ }^{38}$

One of Arnold's achievements in his original Scandal was to have been the first to explore in detail the impact of copyright on Joyce texts and Joyce studies. As I have noted elsewhere, Scandal was helpful to my work in this area. ${ }^{39}$ Arnold enlarges that contribution in the new edition by incorporating analyses of the Joyce Estate's lawsuits against scholars and publishers. Some of these discussions are less than crystal clear, however, such as the attempt to show how the absence of an Irish compulsory license comparable to the one for use of revived-copyright works in the United Kingdom (discussed above) shaped the Estate's litigation against Cork University Press and David Pierce's Irish Writing in the Twentieth Century: A Reader. ${ }^{40}$ And while Arnold correctly begins to address the non-copyright status of the 1922 Ulysses in the United States (113-14), he abandons this for a distracting excursus on the 1934 Random House text and the Little Review installments (116-18), with the result that his discussion of the American copyright situation is overly complex and opaque. He loses the proper focus: the effect of America's copyright law on the 1922 edition. Nevertheless, I applaud Arnold for his efforts in this area; he has gone farther and deeper than many.

\section{Joyce Studies Annual and the Chilling of Traditional Scholarship}

So we have two independently sufficient causes for the nonappearance of John Kidd's edition of Ulysses: copyright problems and the editor himself. A similar overdetermination is suggested by Tom Staley for his decision to terminate Joyce Studies Annual. Staley explains in JSA 2003 that after editing Joyce journals for forty years, his "enthusiasm has waned" but that this is "only half the story" (1). JSA was conceived as a journal that would "publish articles on original materials, archives, textual criticism, bibliography, and biographical research" (1). Now that the Joyce Estate has regularly refused permission to reproduce archival materials-Staley points to the denial of a request 
to publish Joyce's Defoe lecture in a new translation-the primary mission of $J S A$ is thwarted. "Too many potential studies of a textual or bibliographical nature are not undertaken because of the reception their authors would receive when seeking permission from the Estate. One could rail at this recalcitrant position, but to what end?" (1). I have to believe that if copyright obstacles had not interfered with ISA's founding purpose, Staley's enthusiasm might not have flagged. (JSA is now to be published by Fordham University Press under the co-editorship of Moshe Gold and Philip Sicker. ${ }^{41}$ )

This final Texas installment of JSA gives us a valedictory glimpse of the goals which originally animated the journal. The first three essays are important discussions of the content and context of the National Library of Ireland's acquisition in 2002 of what Arnold Goldman calls "an astonishing hoard of previously unknown Joyce manuscripts" (3). Goldman's short piece is followed by a detailed discussion of these new Ulysses materials by Groden, who includes a discursive outline of the collection (7-10), a useful chart of the extant Ulysses manuscripts as of summer 2002, and the place of the NLI purchase within this constellation of documents (13-14). As I noted earlier, Groden contents himself with external description of the NLI papers, carefully designing around any impulse to quote from these examples of Joyce's creative process. Terence Killeen's essay, "Ireland Must be Important . . .," rounds out this part of the volume by surveying the condition of Joyce studies in Ireland during the past forty years, bringing that history up to the NLI's 2002 purchase, which he describes as an example of the new "conspicuous consumption capacity of the Irish State" (36). Killeen voices the hope that "Irish Joyce scholars" and institutions will rise to the challenge posed by this acquisition and the State's official acknowledgment of the importance of studying James Joyce (36). ${ }^{42}$

The remaining essays in the volume represent other scholarly approaches that we have come to expect from JSA. Gareth Joseph Downes offers a detailed exploration of the significance of Giordano Bruno for the young Joyce as he struggled with the claims and influence of the Roman Catholic Church. Densely combining biography, history, and intertextual analysis with close readings of Joyce's own texts-notably, The Day of the Rabblement and Stephen Hero-Downes provides a convincing glimpse into "the intense anger of Joyce's apostasy" and his use of Bruno to effect "a rupture with the hegemony of the Church of his upbringing and education" $(65,70)$. Jürgen E. Grandt skillfully demonstrates that in Zurich Joyce's work on Ulysses underwent a "transformation from a virtuoso performance of English to an innovative composition of language" largely as a result of Joyce's "increasing familiarity with musical notation and the compositional technique of counterpoint" (77). In exploring the "semantic polypho- 
ny" of "Sirens" and other episodes (82), Grandt adds to musicological scholarship on Ulysses by nestling his readings within the biographical details of Joyce's Zurich period, such as his friendships with Otto Luening and Philip Jarnach.

Sicker begins with the premise that treatments of Gerty MacDowell that have cast her as largely an object of masculine fantasy have missed the paradox of her "doubly empowered pleasure as controlling subject and as mastering spectacle" (118). Sicker is at his best when aligning Gerty with certain literary predecessors such as Oscar Wilde's Salomé, who, like Gerty, is "a chaste young woman whose burning sexual desire and power of bodily display operate, under patriarchy, in conjunction with piety and decorum" (104). That seems true to me, as does Sicker's conclusion that Gerty "[savors] erotic subjectivity and, most remarkably, ... briefly [meets] Bloom's gaze" (128).

Keri Elizabeth Ames brings impressive classical learning and familiarity with Homer's Greek to bear on her thesis that "Joyce's depiction of Molly constitutes a mythical affirmation of Homer's Penelope in spite of Molly's affair with Boylan, not a negation or a rejection of Penelope's qualities and values" (133). Ames pursues this insight in skillful detail by insisting upon an unironic parallel between Molly and Penelope, noting, for example, that Joyce allows Molly to share aspects of Penelope and Helen simultaneously, by placing Molly "in the same situation as Penelope, even though Molly is also a version of Helen because Molly has erred and cheated" (143). Ames's analysis is clearly the fruit of long and careful reading of both Joyce's and Homer's texts.

Finally, Friedhelm Rathjen in "James Joyce as a Cyclist" takes a scrap of received biography concerning Joyce's trips to rural Connemara in the summer of 1912 and adjusts the record by attempting to distinguish between when Joyce traveled by bicycle and when he must have gone by train. In lavishing so much erudition on a minor point, Rathjen seeks to remind us that "there is still much in the mass of biographical data about Joyce which should not be taken for granted" $^{\prime \prime}(180)$. This useful little exercise seems an appropriate way to conclude the Texas branch of JSA, on a note of witty biographical questioning and skepticism, and with a gesture towards the riches that remain untapped in the growing archives of the world. Tom Staley is to be congratulated on a long and enviable career as editor of journals and grower of archives.

\section{Resisting the Patentization of Copyrights}

In the patent context, design-arounds expand the knowledge base, inject competition into the marketplace, force patent owners to accept 
sub-monopoly prices, and make a more diverse array of goods and services available to larger numbers of purchasers. They lift some of the deadweight loss created by monopoly. The same cannot be said for design-around scholarship. The humanities are not commerce, and a scholarly monograph is not a widget. The materials that scholars seek to quote and reproduce are not useful ideas and processes but texts, photographs, and other records of richly individualized human subjectivity. While some methods for making do with second-best-fair use and the idea/expression dichotomy, for example-have their time-honored place in humanistic studies when those methods are not too timidly employed, in many cases there really is no substitute for the author's words.

Take Joyce's 1909 letter in which he describes for Nora the ivory necklace he has purchased for her:

Your present is lying before me on the table as I write, ready. ... [ [He describes in great detail the case, the gold chain, the five small ivory cubes, and the larger "tablet" in the center of the chain.] This tablet has on both sides an inscription and the letters are engraved into it.... On the face the words are Love is unhappy and the words on the back are When Love is away. The five dice mean the five years of trial and misunderstanding, and the tablet which unites the chain tells of the strange sadness we felt and our suffering when we were divided. (LettersII 245-46)

Although I have "designed around" my inclination to reproduce Joyce's entire message to Nora, even this excerpt shows that paraphrase could never do justice to Joyce's finely carved melancholy. But more than biographical truth, Joyce's language shows us that the artist and the man cannot be neatly divided, no matter how many times "privacy" is invoked to discourage the use of personal documents. Why are we moved by the letter's strange, poignant mixture of finicking detail and lover's pathos? If we can begin to answer that question by examining this fragment of Joyce's private life, then perhaps we can gain insight into why we are so profoundly affected by the painstaking inventory of the feast in "The Dead" or by the garrulous, sleep-deprived catalogues of "Ithaca." It is Joyce's passionate, compulsive engagement with fact filtered through language, whether the occasion is homely or Homeric, that reminds us of why we read both Ulysses and his letter to Nora. Only hopelessly private persons would deny the continuity between the two.

Design-arounds help a manufacturer stay on the legal side of protected "prior art." But a scholar's use of ultra-safe substitutions for literary art is a different matter. Timid, bloodless paraphrase, unrelieved by forthright detail or fair-use quotation, does not inject a functional equivalent into the intellectual marketplace. Instead, 
we get circumlocution, approximation, vagueness, le mot injuste. Such furtive and unreliable measures go too far. When they are not required by law or practical necessity, let's avoid them-and urge publishers to avoid them. Obtaining copyright permissions may be difficult and sometimes hopeless just now. The public domain cannot hasten to our aid; it moves on a slow wheel. But copyrights are blessedly porous. Let's not give aid and comfort to those who would turn them into patents.

\section{NOTES}

${ }^{1}$ The views expressed in this review essay are my own and not necessarily those of my law firm; the Stanford Law School's Center for Internet and Society, its Cyberlaw Clinic and Fair Use Project; Professor Carol Loeb Shloss; or the James Joyce Quarterly. I would like to thank the following individuals for their helpful comments on drafts of this piece: Laura Barnes, Luca Crispi, Kevin J. H. Dettmar, Judith Harrington, Peter Hirtle, Sebastian Knowles, David S. Olson, David Pierce, Charles Rossman, Paul Saint-Amour, and Lee Zimmerman.

${ }^{2}$ The Federal Circuit has described patent design-arounds as follows:

Keeping track of a competitor's products and designing new and possibly better or cheaper functional equivalents is the stuff of which competition is made and is supposed to benefit the consumer. One of the benefits of a patent system is its so-called "negative incentive" to "design around" a competitor's products, even when they are patented, thus bringing a steady flow of innovations to the marketplace.

Westvaco Corp. v. International Paper Co., 991 F.2d 735, 745 (Fed. Cir. 1993), quoting State Indus., Inc. v. A.O. Smith Corp., 751 F.2d 1226, 1235-36 (Fed. Cir. 1985).

${ }^{3}$ Patents in the United States currently last for twenty years from the date the application is filed with the U. S. Patent Office: 35 U.S.C. § 154(a)(2). That is a much shorter term than author's life plus seventy years, or ninety-five years from the date of publication, which are the current durations of copyrights in the United States. Thus, if copyrights come to resemble patents by losing what I describe in this review essay as their "porosity," copyrights will turn into super-patents because of their great longevity.

${ }^{4}$ See Morrissey v. Proctor \& Gamble Co., 379 F.2d 675, 679 (1st Cir. 1967).

${ }^{5}$ Nichols v. Universal Pictures Corp., 45 F.2d 119, 122 (2d Cir. 1930).

${ }^{6}$ By "market failure," I allude to an important article by Wendy J. Gordon in which she argues that fair use "should be awarded to the defendant in a copyright infringement action when (1) market failure is present; (2) transfer of the use to defendant is socially desirable; and (3) an award of fair use would not cause substantial injury to the incentives of the plaintiff copyright owner" - see "Fair Use as Market Failure: A Structural and Economic Analysis of the Betamax Case and its Predecessors," Columbia Law Review, 82 (December 1982), 1614. Examples of market failure include situations in 
which copyright owners cannot be found or unreasonably refuse to grant permission to quote. Total market failure, as I use the phrase, occurs when the fair-use privilege, though applicable according to Gordon's criteria, cannot be relied upon to remedy a breakdown of bargaining between the copyright owner and the aspiring user-as when a publisher insists that permissions for all scholarly use of quotations, no matter how reasonable or transformative, be obtained.

${ }^{7}$ Paul K. Saint-Amour, review of William M. Landes and Richard Posner, The Economic Structure of Intellectual Property Law (Cambridge: Harvard Univ. Press, 2003), in Modernism/modernity, 12 (September 2005), 511.

8 "Deadweight loss" is a term used to describe the social costs of monopoly; in the present context, it generally signifies under-use of intellectual property. See Christopher Sprigman, "Reform(aliz)ing Copyright," Stanford Law Review, 57 (November 2004), 523-24:

Any copyright system that grants exclusive rights, whether based in a utilitarian or natural/moral rights conception, imposes a number of different social costs. First, there is an obvious economic cost, which is a specific instance of the general problem of monopoly: If a particular creative work has a market value, exclusive rights will enable the creator to charge a supracompetitive price. Consequently, access to the work will be denied to those who value it in excess of the competitive price, but less than the supracompetitive price that the monopolist is able to command. Copyright, then, creates deadweight losses in markets for expression.

When a copyrighted work cannot be used at all because of the owner's exaggerated valuation of the property, then deadweight loss is at its maximum.

${ }^{9}$ Copyrights and other forms of intellectual property are often referred to as "public goods." "A public good is something that is not depleted by use and can be held by more than one person at a time. It can be taken from the owner by others at minimal cost," writes Stephen L. Carter, in "Owning What Doesn't Exist," Harvard Journal of Law and Public Policy, 13 (Winter 1990), 102. Carter continues, noting that public goods are "subject to non-rivalrous consumption, in the sense that one user's use of the idea does not reduce the value of the idea to another who wishes to use it"; it can be used by others "at a cost close to zero" (p. 102).

${ }^{10}$ A photograph of Stephen Joyce's wife, Solange Raythchine Joyce, wearing the necklace may be found at <http:/ / www.themodernword.com/joyce/ jj_stephen_solange.html> (last visited on 28 July 2007).

${ }^{11}$ At least as early as 1988, Stephen Joyce was on record as opposing scholars' use of Joyce family letters in their work. See Caryn James, "Joyce Family Letters in Literary Debate," New York Times (15 August 1988), 13, 15. More recently, D. T. Max, in "The Injustice Collector: Is James Joyce's Grandson Suppressing Scholarship?" The New Yorker (19 June 2006), 35, has described the Joyce Estate's attitude toward unpublished letters, family privacy, and scholarship:

[Stephen Joyce] rejects nearly every request to quote from unpublished 
letters.... Stephen's primary motive has been to put a halt to work that, in his view, either violates his family's privacy or exceeds the bounds of reputable scholarship. The two-decade-long effort has also been an exercise in power-an attempt to establish his own centrality in regard to anything involving his grandfather. If you want to write about James Joyce and plan to quote more than a few short passages, you need Stephen's consent. He has said, "We have proven that we are willing to take any necessary action to back and enforce what we legitimately believe in."

Mr. Joyce also told Max that "the Joyces' private life was 'no one's fucking business'" (p. 36). Further references will be cited parenthetically in the text.

12 This illustration is hypothetical only. I know of no actual refusal to sell Nora's necklace or of an Australian Ph.D. candidate seeking permission to reproduce the 3 September 1909 letter by Joyce. I base my imagined scenario on many public and private statements by representatives of the Joyce Estate regarding the purported urgency of protecting, as Max describes the Estate's position, "what remains of the much abused privacy of the Joyce family" (p. 36).

${ }^{13}$ Lawrence Lessig, "The Creative Commons," Florida Law Review, 55 (July 2003), 775.

${ }^{14}$ I do not address here the obvious limiting case of an unknown, unpublished letter kept under lock and key by its physical owner. While the text of such an occulted document is theoretically a public good, for all practical purposes, the letter is a private good, both as tangible and intangible property. It may be that such a text is not worth thinking of as a public good, just as a tree falling in an unpeopled forest arguably makes no sound. The destruction of such a document may be more an ethical problem than a public-goods problem. While the destroyer might fancy his act a form of familial gallantry, it is also possible to see it as historically and culturally reckless, since, if the letter concerns a figure as important as Joyce, its destruction might (if falling trees in earless forests do make a sound) harm many more people (generations of scholars and students; the public that wants to know) than it protects (a few family members who claim privacy for themselves and the unconsulted deceased author). The moral problem and the public-goods problem converge conspicuously when the owner seeks to suppress the contents of a pub'licly accessible document, not by disporting himself with a box of matches in his attic, but by threatening to enforce a copyright claim in the text.

${ }^{15}$ Gordon, "Excuse and Justification in the Law of Fair Use: Commodification and Market Perspectives," The Commodification of Information: Social, Political, and Cultural Ramifications, ed. Niva Elkin-Koren and Neil W. Netanel (The Hague: Kluwer Law International, 2002), pp. 175-76. Further references will be cited parenthetically in the text as "Commodification."

${ }^{16}$ Adam Smith wrote, in The Wealth of Nations (Chicago: Univ. of Chicago Press, 1976), 4:477:

By preferring the support of domestic to that of foreign industry, [a merchant] intends only his own security; and by directing that industry in such a manner as its produce may be of the greatest value, he intends 
only his own gain, and he is in this, as in many other cases, led by an invisible hand to promote an end which was no part of his intention. Nor is it always the worse for the society that it was no part of it. By pursuing his own interest he frequently promotes that of the society more effectually than when he really intends to promote it.

${ }^{17}$ The necklace that Joyce presented to Nora combined intellectual and physical property by bearing on its ivory tablet a line from one of Joyce's poems. But I am referring to the necklace only in its character as physical chattel.

${ }^{18} \mathrm{~J}$. C. C. Mays, Fredson Bowers and the Irish Wolfhound (Ballybeg, Ireland: Coracle, 2002). Further references will be cited parenthetically in the text.

${ }^{19}$ Carol Loeb Shloss, Lucia Joyce: To Dance in the "Wake" (New York: Farrar, Straus and Giroux, 2003). One of Shloss's critics, John McCourt, in a review of the book in JJQ, 41 (Fall 2003/Winter 2004), 253, has had to admit:

It is hard not to have sympathy for Shloss knowing that she has made it her mission to pluck Lucia from obscurity and give her the place she feels she deserves despite being forced by Joyce's heir to dismantle and delete hard-won material and rewrite this book several times. It is hard not to imagine that much of what I have criticized as speculation may, in fact, be the shadowy remains of what the author was obliged to omit.

Shloss's excisions have been restored on a website created for that purpose at $<w w w . l u c i a-t h e-a u t h o r s-c u t . i n f o /\rangle$. This restoration followed upon the settlement of Shloss's lawsuits against the Estate and Mr. Joyce, described below.

${ }^{20}$ Luca Crispi (formerly James Joyce Research Fellow at the National Library of Ireland and co-curator of the NLI's Ulysses exhibition, and now on the faculty of University College Dublin) has devised an analytical code by which the relationships among pre-publication Ulysses materials, including the important new acquisitions by the NLI, may be perceived at some level of useful generality, and he described it in an email to me on 29 November 2006. For example, Crispi converts the NLI's "Penelope" manuscript into " $x$ " $s$, " $\mathrm{o}$ " $\mathrm{s}$, and full-stops, with the " $\mathrm{x}$ " $\mathrm{s}$ color-coded to indicate main text, interlineal additions, and verso additions. The "o"s point to text that is on the next extant version-for example, the Rosenbach manuscript-with a bold font indicating text that is in that version but not in the NLI draft. Italic text and full-stops are used to indicate additional levels of composition. As ingenious and useful as this is, Crispi himself admits that it is not a "scholarly version because it cannot take into account all the minute but relevant variants, but it is the best way I can find to represent the information without using one copyrighted word."

${ }_{21}$ See, for example, Michael Groden, "The National Library of Ireland's New Joyce Manuscripts: A Statement and Document Descriptions," JJQ, 39. (Fall 2001), 29-51, and "The National Library of Ireland's New Joyce Manuscripts: A Narrative and Document Summaries," Journal of Modern Literature, 26 (Fall 2002), 1-16. The article by Groden that is contained in the volume of Joyce Studies Annual under review here, "The National Library of 
Ireland's New Joyce Manuscripts: An Outline and Archive Comparisons" (pp. 5-17), useful as it is, is another instance of scholarly designing-around.

${ }^{22}$ Despite copyright hindrances, institutional archives strive mightily to bring the benefits of digital media to their collections. For example, the National Library of Ireland's interactive digital displays of the Ulysses manuscripts acquired by the NLI in 2002, which were unveiled during Dublin's 2004 ReJoyce celebrations, are an astonishing educational tool. But the NLI would have been hard pressed to go forward with these displays had it not been for an emergency copyright amendment enacted at the eleventh hour by the Irish legislature in response to purported threats by the Joyce Estate. The amendment specifically allows an institution to place on display an artistic or literary "work, or a copy thereof, in a place or premises to which members of the public have access" - Irish Copyright and Related Rights Act, section 40(7)(a) (as amended). For a lively discussion in the Irish Senate of the amendment and what precipitated it, see Seanad Éireann, vol. 176 (27 May 2004), Copyright and Related Rights (Amendment) Bill 2004: Second Stage (found at <http://historical-debates.oireachtas.ie/S/0176/S.0176.200405270008. $\mathrm{html}>$ (last visited on 28 July 2007)).

${ }^{23}$ See Robert Spoo, Three Myths for Aging Copyrights: Tithonus, Dorian Gray, Ulysses (Dublin: National Library of Ireland, 2004), passim.

${ }^{24}$ The Writ of Summons in the case was issued on 10 June 1997.

${ }^{25}$ See Sweeney v. Macmillan Publishers Ltd., [2001] EWHC Ch $460(22$ November 2001)-available on the British and Irish Legal Information website found at <http://www.bailii.org/ew/cases/EWHC/Ch/2001/460. $\mathrm{html}>$ (last visited on 28 July 2007).

${ }^{26}$ Exceptions to intellectual property, such as fair use, have been compared to the use of easements and eminent domain in the area of real property, According to Dan L. Burk, in "Muddy Rules for Cyberspace," Cardozo Law Review, 21 (October 1999), 158-59, "at least one view of copyright fair use is to view it as a sort of public easement on the copyright owners' property rights, allowing limited access and use to the property if the public interest in the use is sufficiently pronounced."

${ }^{27}$ I allude to the theory of bibliography and textual editing which holds, in contrast to traditional analytical bibliography with its focus on recovering authorial intentions, that "it would now be more useful to describe bibliography as the study of the sociology of texts"-see D. F. McKenzie, Bibliography and the Sociology of Texts (Cambridge: Cambridge Univ. Press, 1999), p. 5. Another major scholar of the social-text edition is, of course, Jerome McGann, who has often cited the late McKenzie as a pioneer in this area. See, for example, McGann, "From Text to Work: Digital Tools and the Emergence of the Social Text," Romanticism on the Net, 41-42 (February-May 2006), passim. Copyrights and copyright law are emerging as forces that must be reckoned with in examining the sociology of texts.

${ }^{28}$ The Estate's "new copyright" motive in approving the Hans Walter Gabler edition, first discussed by Charles Rossman in "The New Ulysses: The Hidden Controversy," New York Review of Books (8 December 1988), 53, is almost always described in ways that muddy the legal and historical issues. Take Bruce Arnold's reference in his revised Scandal of "Ulysses" to "the James Joyce Estate's keen interest in the renewal of copyright" (p. 237). He alludes in the same book to "the legal right of the James Joyce Estate to extend copy- 
right" and to the "new copyright claim for Ulysses based on the re-editing" (pp. 290, 291). Each of these characterizations-'"new copyright," "extend[ed] copyright," "renewal of copyright" - is an inaccurate way of describing a derivative-work copyright; each implies that any copyright claimed for the Gabler text was part of a zero-sum game in which the new monopoly-protected edition would oust all other texts or possible texts, as a matter of law. But when the Random House edition of Gabler's text appeared in 1986, expiration of copyright in all lifetime-published editions of Ulysses was only five years away in the United Kingdom and other parts of Europe. Gabler, Peter du Sautoy, and the edition's advisors knew this. (See the letter from du Sautoy to Philip Gaskell, dated 5 May 1983, in the Richard Ellmann Papers, McFarlin Library Special Collections, University of Tulsa.) Of course, they expected that the new derivative-work copyright in the Gabler Ulysses, combined with the edition's anticipated prestige in the marketplace, would make it the version everyone would want to own. Nevertheless, the legal reality was that alternatives to the Gabler text were then still possible, based upon editions that were soon to shed their copyrights. That prospect receded when copyrights in lifetime-published editions of Lllysses were revived throughout the EU in 1995-though a few projects got through, such as Jeri Johnson's reprint of the 1922 text of Ulysses (Oxford: Oxford Univ. Press, 1993), and the Penguin series of Joyce's works that appeared in the early 1990s under the general editorship of Seamus Deane. However, in an essay in the volume of Joyce Studies Annual under review here, Terence Killeen states that the Penguin "project was dogged by sustained hostility from the James Joyce Estate. It prevented potentially the finest of the editions, J. C. C. Mays's of Poems and Exiles, from achieving completeness" (p. 34). It is likely that some of the materials Mays wished to include had a different copyright status from lifetime-published writings by Joyce which were briefly in the public domain.

${ }^{29}$ See Spoo, "Copyright Protectionism and its Discontents: The Case of James Joyce's Ulysses in America," The Yale Law Journal, 108 (December 1998), 633-67.

${ }^{30}$ David Abel, "Professor Who Rose over Joyce Critique Falls from Grace at BU," Boston Globe (9 April 2002), B1.

${ }^{31}$ This statement is attributed to W. W. Norton's president, Drake McFeely, in Abel's article (p. B1).

${ }^{32}$ Bruce Arnold, The Scandal of "Ulysses": The Sensational Life of a TwentiethCentury Masterpiece (New York: St: Martin's Press, 1991), p. 188. The odd thing is that Arnold leaves the characterization of the Gabler text as an "academic travesty" in his revised Scandal but hedges it about with newly interpolated criticisms of Kidd (p. 230). The result is a lack of coherency about Arnold's ultimate point of view.

${ }^{33}$ This passage from the revised Scandal, like the others quoted here, is not to be found in the 1991 edition. Arnold spliced it into the otherwise relatively uncritical treatment of Kidd remaining from the original 1991 text.

34 "The fact that a work is unpublished shall not itself bar a finding of fair use if such finding is made upon consideration of all the [fair use] factors" -17 U.S.C. $\$ 107$.

${ }^{35}$ Bond v. Blum, 317 F.3d 385, 395 (4th Cir. 2003). See also Rosemont Enterprises, Inc. v. Random House, Inc., 366 F.2d 303, 311 (2d Cir. 1966) (Lumbard, J., concurring: "It has never been the purpose of the copyright laws to restrict the 
dissemination of information about persons in the public eye even though those concerned may not welcome the resulting publicity.")

${ }^{36}$ The concept of intellectual property used as a "scarecrow" to inhibit innovation was advanced by Judge Learned Hand to describe the use of patents to prevent competition-see Bresnick v. U.S. Vitamin Corp., 139 F.2d 239, 242 (2d Cir. 1943).

${ }^{37}$ Copyright misuse is discussed and adjudicated in an increasing number of judicial decisions. See, for example, Intel Corp. \& Dell Inc. v. Commonwealth Scientific \& Industrial Research Organization, 455 F.3d 1364, 1368 (Fed. Cir. 2006); Assessment Technologies of Wisconsin, LLC v. WIREdata, Inc., 350 F.3d 640, 647 (7th Cir. 2003); Practice Management Information Corp. v. American Medical Association, 121 F.3d 516, 520 (9th Cir.1997); and In re Napster, Inc. Copyright Litigation, 191 F. Supp. 2d 1087, 1103 (N.D. Cal. 2002). The doctrine of copyright misuse is discussed in William F. Patry and Richard A. Posner, "Fair Use and Statutory Reform in the Wake of Eldred," California Law Review, 92 (December 2004), 1658-59.

${ }^{38}$ The lawsuits brought by Shloss were entitled Carol Loeb Shloss v. Seán Sweeney and The Estate of James Joyce (case number C 06-3718) and Carol Loeb Shloss v. Stephen James Joyce (case number CV 07-00517) in the Northern District of California federal court. These cases were settled, favorably to Shloss, on 16 March 2007. On Shloss's motion, the court then issued an order requiring the Joyce Estate to pay her attorneys' fees. The amount of fees has yet to be determined. I and my present and former law firms have served as co-counsel for Shloss, along with Lessig and the attorneys at Stanford Law School's Center for Internet and Society and Fair Use Project.

${ }^{39}$ See Spoo, "Copyright Protectionism" (pp. 647 n76, 648 n81, 656 n126).

${ }^{40}$ David Pierce, Irish Writing in the Twentieth Century: A Reader (Cork: Cork Univ. Press, 2000), pp. 310-11.

${ }^{41}$ See Journals: Joyce Studies Annual, found at <http://www.utexas.edu/ utpress/journals/jjsa.html> (last visited 26 November 2006).

42 In September 2006, Anne Fogarty was appointed to a newly created Professorship of James Joyce Studies in the School of English and Drama at University College Dublin. 